\title{
MANAGEMENT PERCEPTIONS OF COMPETENCIES ESSENTIAL FOR MIDDLE MANAGERS
}

\author{
BONGANI MBOKAZI \\ DELÉNE VISSER \\ LINDA FOURIE \\ Programme in Industrial Psychology \\ Department of Human Resource Management \\ Rand Afrikaans University
}

\begin{abstract}
The aim of the study was to establish whether managers at different levels of the organisational hierarchy perceive different managerial competencies as important for middle managers, and whether there were differences between the perceptions of males and females. The participants consisted of 444 senior, middle and first-line managers from a parastatal organisation in Botswana. They completed a questionnaire that assessed their opinions on the importance of six broad competencies for middle managers. It was found that senior managers rated interpersonal competence as more important than middle managers, whereas first-line managers rated operational competence as more important than middle managers. Females perceived analytical and operational competencies as more important than males, whereas males perceived interpersonal competencies as more important than females.
\end{abstract}

\section{OPSOMMING}

Die doel van die studie was om vas te stel of bestuurders op verskillende vlakke van die organisatoriese leer verskillende bestuursbevoegdhede belangrik ag vir middelvlakbestuur en of die persepsies van vroue van dié van mans verskil. Die deelnemers was 444 senior, middel- en eerstevlakbestuurders van 'n semi-staatsorganisasie in Botswana. Die bestuurders het 'n vraelys voltooi waarin hulle hul menings oor die belangrikheid van ses breë bevoegdhede vir middelvlakbestuurders moes aandui. Daar is bevind dat senior bestuurders meer klem op interpersoonlike bevoegdheid as middelbestuurders plaas. Daarteenoor het eerstelyntoesighourers operasionele bevoegdheid as belangriker geag as middelbestuurders. Vroue het analitiese en operasionele bevoegdhede as belangriker beskou as mans en mans het interpersoonlike bevoegdhede as belangriker beskou as vroue.

The momentous changes that have occurred throughout the world over the past decades - the overall economic decline, globalisation, the rapid advances in information technology, looming social disasters such as HIV/AIDS, wide-spread famine, wars and profound political developments across the globe - are enormous by any standard. What is perhaps not always appreciated is that these changes have forever transformed the environment within which organisations have to function (McLagan, 1992: Nel; 1994). These changes, in turn, require that everyone needs to undergo significant transformation of the ways in which they used to operate. Within an organisational context, it appears crucial to develop competent managers who can be entrusted with the responsibility to transform their organisations accordingly. Boyatzis (1982) maintained that it is the competence of managers that, to a large extent, determines the returns that organisations realise from their human capital. Management especially middle management - creates the vital link between the desired economic progress, the required organisational effectiveness and the actual performance of the people involved (Labbaf, Analoui \& Cusworth, 1996; Miller, 1991).

It is clear that management as a process is becoming increasingly dynamic and complex. Middle management in particular comes under enormous pressure to deal with the ever-changing direction from top management on the one hand, and the continuously changing aspirations of society on the other hand. In addition, the immediate organisational environment within which the middle manager has to fulfil his role has also undergone significant changes. Modern day information technology has made information easier to access and share, replacing the middle manager's role as a link in the communication chain. Flatter organisation structures, outsourcing, empowerment and dwindling numbers of middle managers have further transformed the corporate model of management of the past (Galagan, 1990). Job security is being

Requests for copies should be addressed to: D Visser, Department of Human Resource Management, RAU University, PO Box 524, Auckland Park, 2006 replaced by continuous employability, which is only possible if the skills, knowledge and experience of the person remain up to date (Carretta, 1992).

Given the crucial role of the middle manager and the challenges facing this level of management in particular, a key question evolves: What competencies are crucial or essential for middle managers to survive and be effective in these challenging times?

Although research over the past two decades has contributed some wisdom as to the competencies required of managers in general (Bennis \& Nanus, 1985; Bollinger, 1994; Bounds \& Dobbins, 1993; Boyatzis, 1982; Davison, 1994; Hite \& McDonald, 1995; Kouzes \& Posner, 1995; Rhinesmith, 1993; Rost, 1991; Saville \& Holdsworth Ltd. (SHL), 1993; Senge, 1993), conceptual understanding of the particular relationship between management at the top, middle and operational levels is far from clear. Whilst it has been argued that middle management may need a different set of, or emphasis on, specific competencies (Chang, 1996; Ishizaka, 1996), limited literature or research appear to exist which clearly defines the core competencies that middle managers, require to be effective in the workplace.

Although it may be obvious that many factors could affect the competencies that managers - and middle managers in particular - may need, Katz (1974) made it clear that one of the most important factors was precisely the manager's level in the organisational hierarchy. This view is supported by Analoui (1995) who emphasised that a manager's level in the organisational hierarchy is one of the most important determinants of the competencies crucial for the manager's effectiveness. He asserted that a direct relationship exists between the level of seniority of a manager on the one hand, and the perception of the need to acquire or possess certain categories of competence on the other hand. Although his research was limited in scope and primarily focused on senior management, it may be inferred that similar implications exist as far as middle management is concerned. 
Apart from a manager's level in the organisational hierarchy, other factors also appear to play a role in determining the specific managerial competencies required for managerial effectiveness. Emerging views from literature on diversity indicate that differences in management styles, management preferences and required managerial competencies may exist within diverse contexts such as developing versus developed societies, minority versus majority constituencies, male versus female employees, and among different race and culture groupings. It has been argued that great benefit is to be derived from introducing diversity into management; that previously disadvantaged groups have a significant and unique management contribution to make; that female executives bring different competencies to organisations and that they should therefore be advanced in organisations, not simply as an affirmative action imperative; and that those businesses that reshape their senior management to include the best talent from the total work force will be far ahead of the competition in the global market place (Adler, 1994; Blanchard, 1989; Hofmeyer, 1990; Human \& Human, 1989; Jorgensen, Hafsi \& Kiggundu, 1986; Khoza, 1994, 2002; Mbigi, 1994; Segal, 1991; Simons, 2000; Van der Merwe, 1994).

It is against this background that many secondary questions evolve: Are different managerial competencies required by organisations within a developing versus a developed context? Are different managerial competencies valued and required by male and female employees? Do employees from different race and culture groups regard different competencies as important?

The aim of this study, therefore, was to explore mainly two questions: Firstly, whether different levels of management perceive different managerial competencies as important for middle managers, and secondly, whether different managerial competencies are perceived to be important by male and female managers. The study was undertaken within the context of an organisation in a developing country to add specific insights into the needs at this level. It was believed that the identification of the relative importance of different managerial competencies would allow human resource management processes such as recruitment and selection, training and development, as well as assessment and remuneration, to be more focused and more cost effective.

\section{The concept of competencies}

Boyatzis (1982) introduced the concept of competencies that became very popular in the late 1980s. He defined a competency in a broad, generic form as any underlying characteristic an individual possesses and uses which leads to successful performance in a life role. Many authors have subsequently explored the concept and two approaches appear to have found favour. The first approach placed emphasis on the behavioural aspect of a competency by defining it as a set of behaviour patterns that the incumbent needs to bring to a position in order to perform its tasks and functions with competence (Human \& Human, 1989; Meyer, 1996; Schroder, 1989; Vincent, 1988; Woodruffe, 1993). Central to this view is the notion that a competency is a dimension of overt and manifest behaviour that allows a person to perform competently, incorporating both the desire and the ability to behave in a competent way. The British Management Initiative aligned itself with this view when it defined a competency as the ability to perform activities within an occupation to the standards expected in employment (Boutall, 1995). These standards are expressed as elements of a competence.

The second approach appears to be more aligned to the initial description of Boyatzis (1982) in terms of which a competency is viewed broadly as an underlying characteristic of an employee (i.e. motive, trait, observable skills, aspects of one's self-image, social role, or a body of knowledge) that enables him to complete a task successfully. This view is supported by authors such as Jacobs (1989) and Dubois (1993) and defined in greater detail by Scott (1996) when he described a competency as a cluster of related knowledge, attitudes and skills that affects a major part of one's job (a role or responsibility) and that correlates with performance on the job, which can be measured against well-accepted standards, and which can be improved through training and development. What is worth noting in this definition is that it combines knowledge, skills, behaviour and attitude into one core unit, called a competency.

For the purpose of the present study the latter approach was preferred. Implied in both approaches though, is the notion that a specific competency can be described and should be measurable. This understanding of the concept of a competency provides a useful background for further discussion on the subject of management competencies.

\section{Management competencies}

Developing and training of management on key competencies have become the focus of much attention during the past two decades (Adler, 1994; Hite \& McDonald, 1995; Kakabadse, Ludlow \& Vinnicombe, 1987; Leblanc, 1994; Margerison, 1984a; Margerison, 1985). Attempts have been made to identify a set of competencies and their implications in the areas of management education and development, to further the development of competent managers. Corresponding with the overwhelming emphasis on the competency approach to management development and along with it, its increased acceptability, several taxonomies of managerial competence have been put forward (Analoui, 1995; Cockerill, Hunt \& Schroder, 2000; Education Review Office, 1995; Katz, 1974; Mann \& Staudenmier, 1991; Mintzberg, 1980; Peter, 1984; Profiles International, 2000; SHL, 1994; Williamson, 1981) These theories indicate a myriad of key competencies, which are briefly summarised in Table 1 .

Increasing consensus, backed by authorities such as SHL (1993), Schroder (1989) and Vincent (1988), has built up over the years suggesting that it is possible to create a universal or core competency model for the assessment of managers. Three broad domains of managerial competence appear to emerge: Firstly, the competency to manage the task; secondly, the competency to manage people and thirdly, the competency to manage the "self". These emerging domains of competence are clearly noticeable from Table 1.

Authors such as Adler (1994), Analoui (1995), Kakabadse et al., (1987), Labbaf et al., (1996), Livingstone, (1977), Margerison (1984b), and Stewart (1987) indicated that managers require competencies for managing themselves, competencies to manage other people and competencies to manage the task. Schein (1987) placed emphasis on the responsibility of the manager to firstly set objectives, plan, take decisions, and organise work in the organisation. The second task requires the ability to motivate, measure, control and develop other people. Clearly the focus in this instance is on managing both the task and the people.

The competency to manage people appears to be especially important for managers. In a study conducted by Reichel (1996) in Israel, 240 executives were involved in an attempt to establish which competencies were important for management development. The findings indicated that the executives believed that any managerial programme should first focus on and emphasise behavioural skills (interpersonal competencies). Concurring with these findings are those from a study in the finance sector in the UK indicating again that managing interaction (interpersonal competencies) was the most important competence for managerial effectiveness (Goffee, 1996). A further study in the steel industry in Iran also confirmed the importance of people-related competencies in ensuring the effectiveness of (senior) managers (Labbaf et al., 1996). The study indicated that senior managers perceived self-management and people-related competencies as more important for their effectiveness than taskrelated competencies. Jackson and Humble (1994), with special 
TABLE 1

KEY COMPETENCIES FOR MANAGEMENT

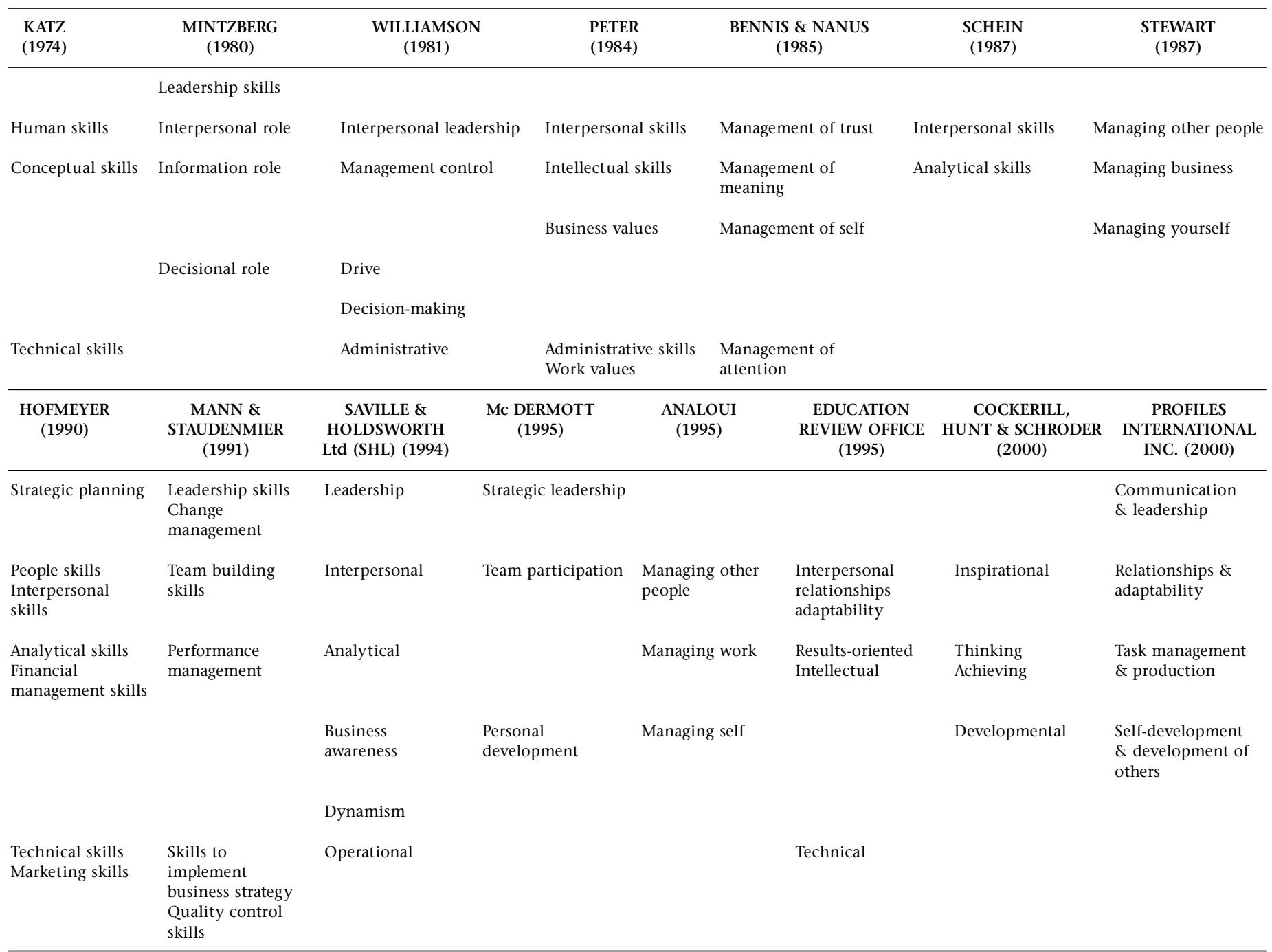

reference to middle managers, concluded that the interpersonal competencies often associated with educators, consultants and counsellors are becoming increasingly important for the effectiveness of the manager. In a study conducted by Adler (1994) female managers indicated that their effectiveness in management, especially in foreign countries, was attributed largely to their interpersonal competencies.

The importance of the competency to manage the "self" has only recently attracted attention as a major component of managerial effectiveness (Labbaf et al., 1996). Behavioural self-management is viewed as a basic requirement for increased managerial effectiveness (Analoui, 1995; Davis, Hellervik \& Sheard, 1989; Galagan, 1990; McDermott, 1995; SHL, 1993). It is asserted that self-management sets a ceiling for managerial effectiveness. This implies that managers must first ensure their self-development as a continuous process of personal and professional growth, before acquiring sufficient related managerial competencies to manage the task and the people.

A competency model that appears to encompass many aspects of current thinking on managerial competence is one developed by SHL (1994). Based on extensive work in the fields of job analysis and competency-based assessment centres, SHL initially introduced a management competency model called the Inventory of Management Competencies (IMC) that identified 16 core managerial competencies. Further analysis of the 16 competency scales highlighted the need for a more detailed assessment of competencies - especially within a development context - and a more detailed competency model, Perspectives on Management Competencies (PMC), emerged to complement the IMC. The PMC model comprises 36 detailed managerial competency scales covering six broad dimensions of managerial competence (see Table 2).

This model was adopted as a premise for this study, because it apparently covered many of the managerial competency dimensions mentioned in the research referenced above and furthermore followed a strong competency-based approach which has great value in many competency-based human resource management applications.

\section{Focus of the study}

The state of current theory appears to converge around the idea that managerial competence could be clustered into the competency dimensions of task, people and self-management competencies. However, the notion that different levels of management require different sets of, or different emphasis on, specific competencies emerges as clearly. Earlier reference to the work of Analoui (1995), Katz (1974) and Labbaf et al. (1996) strongly suggested that the hierarchical level of the manager has an influence on the relative importance of the different managerial competencies. Although the importance of the people management competency for middle managers is often stressed, the specific relationship between this particular competency on the one side, and the competencies of task and self-management on the other side, is not made explicit. Given this degree of uncertainty, it was believed that the present study 
could add insight into defining the perceived importance of different managerial competencies required for effective performance at this level.

TABLE 2

SHL PERSPECTIVES ON MANAGEMENT COMPETENCY MODEI

\begin{tabular}{ll}
\hline LEADERSHIP & INTERPERSONAL \\
- Providing direction & - Interpersonal sensitivity \\
- Empowering & - Teamwork \\
- Motivating & - Building and maintaining \\
- Delationships \\
- Attracting and developing talent & - Integrity \\
& - Flexibility \\
- Stress tolerance \\
ANALYTICAL & - Tenacity \\
- Judgment & BUSINESS AWARENESS \\
- Information gathering & - Organisational awareness \\
- Problem solving & - Strategic perspective \\
- Objective setting & - Commercial orientation \\
- Management control & - Innovation \\
- Written communication skills & - Career and self development \\
- Technical skill and competence & \\
DYNAMISM & \\
- Self confidence & OPERATIONAL \\
- Impact & - Concern for excellence \\
- Decisiveness & - Customer service orientation \\
- Drive & - Execution \\
- Initiative & \\
- Persuasiveness & \\
- Oral communication & \\
\hline
\end{tabular}

Adapted from SHL (1994)

Earlier reference to the work of Adler (1994), Betters-Reed and Moore (1995), Blanchard (1989), Hofmeyer (1990), Larwood and Wood (1995), Lewis and Fagenson (1995), Mbigi (1994) and others further suggested that gender differences might exist in terms of managerial styles, managerial preferences and required managerial competencies. Although emphasis is placed on the importance of the interpersonal or people-related dimensions of managerial competence for females in particular, the specific relationship between this competency on the one side, and the competencies of task and self-management on the other side is again not made explicit. It was believed, therefore, that this study could also add insight into defining the relative importance of specific managerial competencies required for effective managerial performance from a gender-specific point of view.

In addition, it was assumed that much of the management research has taken place in the context of well-developed organisations and societies. An increasingly globalised world, however, demands increased emphasis on similarities or differences in approaches required within the context of developing organisations and societies. The context within which the present study was undertaken - namely the Botswana Telecommunications Corporation - may be viewed as typical of a developing organisational and societal context.

Botswana has the distinction as being one of the most rapidly developing countries in Africa (Tlou \& Campbell, 1997) and today enjoys one of the highest economic growth rates in the world (Botswana Telecommunications Corporation, 2000). Riding on the wave of sustained economic growth was the emergence of a number of public enterprises which were developed as an extension of government programmes such as citizen empowerment and advancement of economic competitiveness
(Cowan, 1990; Haque, 1996; Kumssa, 1996; Mbokazi, 1991; Sebettela, 2000). However, the development of the country's estimated 1.7 million people (Central Statistics Office, 1999) has not kept pace with the rapid economic developments, nor adequately prepared human resources to be effective in a constantly changing environment. As a result, a huge shortage of skills exists across the board (Botswana Guardian, 2000; Botswana Communications Corporation, 2000) and the need for and importance of developing managerial competence is obvious.

It is against this background that two hypotheses were stated. The first hypothesis was that the perceived importance of a set of managerial competencies required for middle managers would differ significantly, depending on the hierarchical level of management involved in the rating. The second hypothesis was that female managers would rate interpersonal competence as more important than their male counterparts.

\section{METHOD}

\section{Participants}

The research was conducted at a large parastatal organisation in the telecommunications sector in Botswana. A random sample of 550 managers was selected using the SPSS software. A certain degree of natural attrition occurred. Some managers were on sick, study or annual leave during the period of the study. Finally, 444 respondents participated, which was $81 \%$ of the original random sample. Forty respondents $(9.1 \%$ of the sample) were senior managers. One hundred and eighty seven respondents (42.7\%) were middle managers. The first-line management level was represented by 211 respondents ( $48.2 \%$ of the sample). There were 331 males (74.5\%) and 113 females (25.5\%) in the sample. The sample represented citizens $(91.2 \%)$ and expatriate employees (8.8\%).

The ages of the respondents varied between 17 and 66 years, with a mean of $34.80(\mathrm{SD}=8.29)$. The majority of the participants were Batswana (91\%) and their home language was Setswana (82.4\%). The participants' years of management experience ranged from 1 to 27 years $($ Mean $=7.02, \mathrm{SD}=4.81)$. Their qualifications ranged from Junior Certificate/Standard 8 to doctoral degrees (JC/Std 8 - Diploma $=26 \%$, Diploma $=35 \%$ and above Diploma $-39 \%$ ).

\section{Measuring instrument}

Data was collected using the PMC questionnaire developed by SHL (1994). The six management competencies according to the SHL model are the leadership, interpersonal, analytical, business awareness, dynamism, and operational competencies.

The questionnaire from SHL was used without significant changes. The only two changes that were made were firstly, to remove the names of competencies above each question so as to remove the possibility of influencing participants by titles given to the competencies. Secondly, a seven-point scale was introduced $(1=$ less important and $7=$ extremely important $)$ instead of using the SHL four-point scale (basic, moderate, high and extreme). These adaptations were made with the approval of SHL-South Africa. The questionnaire is normally used for job profiling and developmental purposes. In this study the questionnaire was used to measure the extent to which competencies are regarded as important for the effectiveness of middle managers. Respondents from different levels of management were asked to rate the competencies on a sevenpoint scale. As a result of the different use of the SHL instrument envisaged for the present study, the psychometric functionality of the instrument had to be investigated.

The reliabilities of the various competencies comprising the measuring instrument are reported in the questionnaire manual (SHL, 1994). Internal consistency reliabilities of the PMC scales based on self-ratings and others' ratings combined ranged from 0.54 to 0.87 , on self-ratings only from 0.44 to 0.87 , and on others' ratings only from 0.65 to 0.87 . 
Procedure

A pilot study was carried out to establish whether the prospective participants would understand the questionnaire and to standardise the measurement procedure. A group of 14 potential participants, who belonged to first-line, middle and senior managerial levels, was chosen to complete the questionnaire and to make comments on the sensitivity of the biographical questions relating to race, home language, education and age. They were also asked to comment on the ability of the first-line managers to comprehend the meaning of the items and the words/phrases used in the questionnaire.

This exercise proved useful, because some of the biographical questions had to be changed as a result. Thirteen out of fourteen respondents indicated that the level of English used in the questionnaire was comprehensible for first-line managers. They further suggested that the few identified words that might be regarded as difficult, be explained during the administration session. After identification of the participants through a random sampling method, they were grouped by proximity of departments or geographical area. Group sessions were held. The researcher administered the questionnaire to the respondents after informal rapport had been established. The researcher explained the purpose of the study and answered questions from the respondents addressing their concerns.

\section{RESULTS}

The means and standard deviations of the perceptions of the six SHL competencies by different levels of management are presented in Table 3. Internal consistency reliabilities for the six competencies ranged between 0.59 and 0.83 . Similarly, the means and standard deviations of the perceptions of the six competencies by gender are presented in Table 4 .

TABLE 3

DESCRIPTIVE STATISTICS OF THE SIX COMPETENCIES BY LEVELS OF MANAGEMENT

\begin{tabular}{|c|c|c|c|c|c|c|c|c|c|}
\hline \multirow[t]{3}{*}{ Competencies } & \multicolumn{8}{|c|}{ Levels of management } & \multirow{3}{*}{$\begin{array}{c}\text { Cronbach } \\
\text { alpha }\end{array}$} \\
\hline & \multicolumn{2}{|c|}{$\begin{array}{l}\text { First-Line } \\
(\mathrm{N}=190)\end{array}$} & \multicolumn{2}{|c|}{$\begin{array}{c}\text { Middle } \\
(\mathrm{N}=175)\end{array}$} & \multicolumn{2}{|c|}{$\begin{array}{c}\text { Senior } \\
(N=38)\end{array}$} & \multicolumn{2}{|c|}{$\begin{array}{c}\text { Total } \\
(\mathrm{N}=403)\end{array}$} & \\
\hline & $\mathbf{M}$ & SD & $\mathbf{M}$ & SD & $\mathbf{M}$ & SD & M & SD & \\
\hline Leadership & 6.00 & 0.71 & 6.01 & 0.61 & 6.20 & 0.65 & 6.02 & 0.67 & 0.67 \\
\hline Interpersonal & 5.47 & 0.74 & 5.33 & 0.67 & 5.72 & 0.62 & 5.44 & 0.71 & 0.81 \\
\hline Analytical & 5.14 & 0.98 & 5.95 & 0.90 & 5.16 & 0.85 & 5.06 & 0.94 & 0.83 \\
\hline $\begin{array}{l}\text { Business } \\
\text { Awareness }\end{array}$ & 4.94 & 0.91 & 4.92 & 0.83 & 4.91 & 0.85 & 4.93 & 0.87 & 0.77 \\
\hline Dynamism & 5.56 & 0.74 & 5.78 & 0.56 & 5.80 & 0.44 & 5.68 & 0.65 & 0.77 \\
\hline Operational & 5.92 & 0.83 & 5.63 & 0.78 & 5.84 & 0.77 & 5.78 & 0.82 & 0.59 \\
\hline
\end{tabular}

TABLE 4

DESCRIPTIVE STATISTICS OF THE SIX COMPETENCIES BY GENDER

\begin{tabular}{lccccc}
\hline Competencies & \multicolumn{3}{c}{ Gender } \\
& Male $(\mathrm{N}=308)$ & \multicolumn{2}{c}{ Female $(\mathrm{N}=101)$} \\
& $\mathrm{M}$ & $\mathrm{SD}$ & $\mathrm{M}$ & $\mathrm{SD}$ \\
\hline Leadership & 6.04 & 0.65 & 5.96 & 0.71 \\
Interpersonal & 5.41 & 0.66 & 5.33 & 0.83 \\
Analytical & 4.98 & 0.90 & 5.36 & 0.90 \\
Business Awareness & 5.00 & 0.87 & 5.06 & 0.86 \\
Dynamism & 5.69 & 0.63 & 5.65 & 0.71 \\
Operational & 5.73 & 0.81 & 5.97 & 0.81 \\
\hline
\end{tabular}

The 36 items of the competency questionnaire from SHL were subjected to an exploratory factor analysis to establish whether the data obtained in the present study supported the model of six competencies proposed by SHL. Firstly, it was determined whether the sample was adequate and whether it was justified to perform a factor analysis on the questionnaire. The KaiserMeyer-Olkin measure of sampling adequacy was 0.85 indicating that the sample was appropriate. The Bartlett test of sphericity indicated that the variables yielded a statistically significant approximate chi-square $\left[\chi^{2}(630)=6727.80\right.$, $\mathrm{p}<0.001]$. These tests provided sufficient justification to proceed with the factor analysis.

Ratings on the 36 items of the SHL questionnaire were subjected to a principal axis factor analysis, which resulted in eight factors being extracted that explained $61.50 \%$ of the variance. The factor matrix was rotated to a simple structure using the varimax rotation procedure. As a result of the high correlations between certain factors (see Table 5), it was decided to perform a secondorder factor analysis, which would yield even fewer factors. The Kaiser-Meyer-Olkin measure of sampling adequacy for the second factor analysis was 0.74 , indicating that the sample was appropriate. The Bartlett test of sphericity yielded a statistically significant approximate chi-square $\left[\chi^{2}(28)=792.64, \mathrm{p}<0.001\right]$. The principal axis factor analysis resulted in three factors being extracted that explained $68.35 \%$ of the variance. The factor axes were subsequently rotated using the direct oblimin rotation procedure. The factor pattern matrix and the factor intercorrelation matrix are reported in Tables 6 and 7.

TABle 5

\section{INTERCORRELATION MATRIX OF THE FIRST-ORDER FACTORS}

First-order Factor 1 Factor 2 Factor 3 Factor 4 Factor 5 Factor 6 Factor 7 Factor 8 factors

\begin{tabular}{lllllllll}
\hline Factor 1 & 1.00 & & & & & & \\
Factor 2 & 0.18 & 1.00 & & & & & \\
Factor 3 & 0.61 & 0.12 & 1.00 & & & & \\
Factor 4 & 0.21 & 0.36 & 0.14 & 1.00 & & & \\
Factor 5 & 0.02 & 0.52 & 0.05 & 0.10 & 1.00 & & \\
Factor 6 & 0.30 & 0.44 & 0.26 & 0.36 & 0.30 & 1.00 & \\
Factor 7 & 0.26 & 0.31 & 0.33 & 0.02 & 0.28 & 0.33 & 1.00 & \\
Factor 8 & 0.48 & 0.22 & $\mathbf{0 . 5 2}$ & 0.10 & 0.14 & 0.27 & 0.29 & 1.00 \\
\hline
\end{tabular}

TABLE 6

FACTOR PATTERN MATRIX OF THE SECOND-ORDER PRINCIPAL AXIS FACTOR ANALYSIS

Second-order factors

\begin{tabular}{lcccc}
$\begin{array}{l}\text { First-order } \\
\text { factors }\end{array}$ & Factor 1 & Factor 2 & Factor 3 & $\mathbf{h}^{\mathbf{2}}$ \\
\hline Factor 3 & 0.85 & -0.11 & -0.02 & 0.67 \\
Factor 1 & 0.74 & -0.08 & 0.13 & 0.56 \\
Factor 8 & 0.61 & 0.10 & -0.03 & 0.41 \\
Factor 2 & 0.02 & 0.72 & 0.24 & 0.64 \\
Factor 5 & -0.11 & 0.72 & -0.05 & 0.47 \\
Factor 7 & 0.33 & 0.40 & -0.17 & 0.34 \\
Factor 6 & 0.21 & 0.39 & 0.26 & 0.37 \\
Factor 4 & 0.04 & 0.05 & 0.77 & 0.62 \\
\hline
\end{tabular}


TABLE 7

INTERCORRELATION MATRIX OF THE SECOND-ORDER FACTORS

\begin{tabular}{lccc}
\hline $\begin{array}{l}\text { Second-order } \\
\text { factors }\end{array}$ & $\begin{array}{c}\text { Self- } \\
\text { management/ } \\
\text { Leadership }\end{array}$ & $\begin{array}{c}\text { Interpersonal/ } \\
\text { Analytical }\end{array}$ & $\begin{array}{c}\text { Strategic } \\
\text { planning }\end{array}$ \\
\hline $\begin{array}{l}\text { Self-management } \\
\text { Leadership }\end{array}$ & 1.00 & & \\
$\begin{array}{l}\text { Interpersonal/ } \\
\text { Analytical }\end{array}$ & 0.31 & 1.00 & \\
Strategic Planning & 0.15 & 0.20 & 1.00 \\
\hline
\end{tabular}

The contents of the items defining each factor were studied with the aim of assigning appropriate descriptive labels for every factor. Tentative labels were assigned (see table 7), but the combination of items per factor did not allow for meaningful psychological interpretation. It was therefore decided to disregard the results of the factor analysis and to proceed with the testing of the hypotheses using the SHL six-competency model.

\section{Management level differences}

In order to test whether managers at various levels of the organisation perceived the importance of competencies differently, a one-way MANOVA was performed on the six competencies proposed by SHL. The MANOVA was conducted using the level of management as independent variable and the importance perceptions as dependent variables. Wilk's lambda was utilised to determine whether the perceptions of managers differed significantly. The obtained lambda of 0.894 with associated $F(12)=3.81, p<0.001$, was statistically significant. Significant differences between the three levels of management were obtained for the Interpersonal, Dynamism and Operational competencies. The results of the $\mathrm{F}$ tests are given in Table 8.

TABLE 8

MANOVA SUMMARY TABLE FOR THE PMC SCALES WITH LEVEL OF MANAGEMENT AS INDEPENDENT VARIABLE AND THE SIX SHL COMPETENCIES AS DEPENDENT VARIABLES

\begin{tabular}{lccccccccc}
\hline & $\begin{array}{c}\text { Levene's test } \\
\text { of equality of } \\
\text { error variance }\end{array}$ & & \multicolumn{2}{c}{ Tests of between-subjects effects } \\
Competencies & $\mathrm{F}$ & $\mathrm{p}$ & $\mathrm{Ss}$ & $\mathrm{df}$ & $\mathrm{ms}$ & $\mathrm{F}$ & $\mathrm{p}$ & $\eta^{2}$ \\
\hline Leadership & 1.58 & 0.208 & 1.33 & 2 & 0.66 & 1.50 & 0.224 & 0.01 \\
Interpersonal & 1.52 & 0.219 & 4.90 & 2 & 2.45 & 4.99 & 0.007 & 0.02 \\
Analytical & 4.08 & 0.018 & 3.50 & 2 & 1.75 & 2.01 & 0.135 & 0.01 \\
Business Awareness & 1.04 & 0.354 & 3.69 & 2 & 1.80 & 0.02 & 0.976 & 0.00 \\
Dynamism & 9.33 & 0.000 & 5.03 & 2 & 2.52 & 6.08 & 0.002 & 0.03 \\
Operational & 1.01 & 0.036 & 7.85 & 2 & 3.92 & 6.06 & 0.003 & 0.03 \\
\hline
\end{tabular}

Wilks lambda $=0.89$

$\mathrm{F}(12)=3.81, \mathrm{p}<0.001$

$\eta^{2}=0.06$

Post hoc tests, using Scheffe's procedure or Dunnett's test (depending on the homogeneity of variances) were subsequently performed on the Interpersonal, Dynamism and Operational variables to investigate between which levels of management the perceptions differed significantly. The results are reflected in Table 9.
TABLE 9

COMPARISONS OF LEVELS OF MANAGEMENT MEAN SCORES ON THE SIX SHL COMPETENCIES

\begin{tabular}{lllcc}
\hline Competency & $\begin{array}{c}\text { Level of } \\
\text { management }\end{array}$ & $\begin{array}{c}\text { Level of } \\
\text { management }\end{array}$ & $\begin{array}{c}\text { Mean } \\
\text { difference }\end{array}$ & $\mathrm{p}$ \\
\hline Interpersonal & First-Line & Middle & 0.13 & 0.192 \\
& Middle & Senior & -0.24 & 0.148 \\
Dynamism & First-Line & Middle & -0.38 & 0.011 \\
& Middle & Senior & -0.22 & 0.004 \\
& First-Line & Senior & -0.24 & 0.105 \\
Operational & & Middle & 0.29 & 0.987 \\
& Middle & Senior & 7.54 & 0.870 \\
& & Senior & -0.22 & 0.328 \\
\hline
\end{tabular}

Senior managers rated the Interpersonal competency significantly higher than the middle managers $(p=0.011)$. Middle managers rated the Dynamism competency significantly higher than first-line managers $(\mathrm{p}=0.004)$ and first-line managers rated the Operational competency significant higher than middle managers $(p=0.003)$.

\section{Gender differences}

In order to test whether male and female managers perceived the importance of competencies differently, a one-way MANOVA was conducted on the six SHL competencies using gender as the independent variable and the importance perceptions as the dependent variables. Hotelling's trace was utilised to determine whether the perceptions of males and females differed significantly. The obtained Hotelling $\mathrm{T}^{2}$ of 0.05 with associated $F(6)=3.56, p=0.002$ was statistically significant. Significant differences between males and females were obtained for the Interpersonal, Analytical and Operational competencies. The results are reported in Table 10. Males regarded the Interpersonal competency as more important than females $(\mathrm{p}=0.047)$, whereas both the Analytical $(p<0.001)$ and Operational $(p=0.013)$ competencies were regarded as more important by females than males.

TABLE 10

MANOVA SUMMaRy TABLe For THE PMC SCALES WITH GENDER AS INDEPENDENT VARIABLE AND THE SIX SHL COMPETENCIES AS DEPENDENT VARIABLES

\begin{tabular}{ll}
\hline Levene's test & $\begin{array}{l}\text { Tests of between-subjects effects } \\
\text { of equality of } \\
\text { error variance }\end{array}$
\end{tabular}

\begin{tabular}{lcccccccc} 
Competencies & $\mathrm{F}$ & $\mathrm{p}$ & $\mathrm{Ss}$ & $\mathrm{df}$ & $\mathrm{ms}$ & $\mathrm{F}$ & $\mathrm{p}$ & $\eta^{2}$ \\
\hline Leadership & 1.08 & 0.300 & 0.54 & 1 & 0.54 & 1.23 & 0.267 & 0.00 \\
Interpersonal & 10.52 & 0.001 & 1.97 & 1 & 1.97 & 3.98 & 0.047 & 0.01 \\
Analytical & 2.91 & 0.089 & 10.8 & 1 & 10.8 & 12.72 & 0.000 & 0.03 \\
Business Awareness & 0.05 & 0.820 & 1.91 & 1 & 1.91 & 2.56 & 0.110 & 0.01 \\
Dynamism & 5.53 & 0.019 & 0.15 & 1 & 0.15 & 0.36 & 0.551 & 0.00 \\
Operational & 0.11 & 0.744 & 4.10 & 1 & 4.10 & 6.23 & 0.013 & 0.02
\end{tabular}

Hotelling s trace $=0.05$

$\mathrm{F}(6)=3.56, \mathrm{p}=0.002$

$\eta^{2}=0.05$ 


\section{DISCUSSION}

The purpose of the study was to identify competencies or categories of competencies that are essential for middle managers and to establish whether there were any differences in perceptions between levels of management and also between male and female managers.

In Table 3 the relative importance that managers at different levels of the organisation attach to the six competencies, are presented. It is clear that the managers at all three levels regarded all six competencies as important, but it was found that there were significant differences with regard to the perceived importance of some competencies between the managers from the three levels. The one-way MANOVA performed on the six SHL competencies indicated significant differences between the importance perceptions of the three levels of management with regard to the Interpersonal, Dynamism and Operational competencies. Senior managers rated the Interpersonal competency significantly higher than middle managers. Middle managers rated the Dynamism competency significantly higher than first-line managers, and first-line managers rated the Operational competency significantly higher than middle managers. There were no significant differences in perceptions of managers at different levels with regard to the Leadership, Analytical, and Business Awareness competencies.

It is interesting to note the relative importance that managers at every level in the hierarchy attached to the leadership and dynamism competencies, indicating the value of the competence to lead others with enthusiasm and confidence. In comparison, the lower value attached to the business awareness competence may be an affirmation that middle management is perceived to be generally more concerned with operational tasks than with broader organisational or strategic issues. These results appear to support the findings of Analoui (1995), Goffee (1996) and others that people-management and selfmanagement competencies are indeed perceived as important for managerial effectiveness.

In terms of gender there were significant differences between the importance perceptions of male and female managers with regard to the Interpersonal, Analytical and Operational competencies. An unexpected result was the finding that males perceived the Interpersonal competency as more important for middle managers than females. On the other hand, the Analytical and Operational competencies were regarded as more important by females than by males. The expectation was that males would rate Operational and Analytical competencies higher than females would (Mbigi, 1994; Segal, 1991) and that female managers would rate the Interpersonal competency higher than males would (Adler, 1994; Mbigi, 1994; Segal, 1991). This unexpected finding can possibly be explained by the view that although female managers consider themselves possessing interpersonal competencies as an advantage (Adler, 1994; Van der Merwe, 1994), they do not necessarily perceive these to be especially important for the effectiveness of middle managers. The same applies to males. Although they may consider themselves strong in the task-management competencies (Mbigi, 1994; Segal, 1991), they do not necessarily perceive these to be especially important for the effectiveness of middle managers.

Ishizaka (1996) correctly pointed out that, in this rapidly changing environment, the quality and quantity of the human resources is the decisive factor for the continued innovation and creation in all facets of the organisation. Inevitably, this demands from management appropriate skills, attitudes and behaviour to facilitate these processes. In this context, it has become vital to develop middle managers that can integrate organisational activity across the different hierarchical levels.
One strategy that could help organisations achieve the aforementioned objective is to predict effective job performance by selecting, training and placing people into appropriate jobs. The use of competencies has been recommended and has proved to be successful for such efforts (Boyatzis, 1982; Denge, 1991; Digman, 1978; Dubois, 1993; Hayes, 1983; McClelland, 1973). It is believed that the present study has made a meaningful contribution towards this aim by highlighting the perceived importance of specific competencies required for the effective performance of middle managers in particular.

In conclusion, it is important to indicate limitations of the study as a pointer for future research. This study was conducted in a specific organisation. As mentioned earlier, the organisation from which the participants were drawn operates within a specific socio-political and economic context. The findings should therefore not be generalised to managers in other organisational contexts without a degree of circumspection. For future research, there will be value in exploring whether the same results are found if the study were to be conducted in a different industry or different organisational context. It will also be invaluable to establish whether significant differences in the importance perceptions of different race or cultural groupings of managers exist. It is in the analyses of these differences that diverse approaches to management may be discovered, aiding organisations in valuing what diversity in management might bring to organisational effectiveness.

\section{REFERENCES}

Adler, N. (1994). Competitive frontiers: Women managing across borders. Journal of Management Development, 13 (2), 24-41.

Analoui, F. (1995). Management skills and senior management effectiveness. International Journal of Public Sector Management, 8 (3), 52-68.

Bennis, W. \& Nanus, B. (1985). Leaders: The strategies for taking charge. New York: HarperCollins.

Betters-Reed, B.L. \& Moore, L.L. (1995). Shifting the management development paradigm for women. Journal of Management Development, 14 (2), 24-38.

Bollinger, D. (1994). The four cornerstones and three pillars in the "House of Russia" management system. Journal of Management Development, 13 (2), 49-54.

Blanchard, K. H. (1989). The power of ethical management. New York: William Morrow.

Bounds, G.M. \& Dobbins, G.N (1993). Changing the managerial agenda. Journal of General Management, 18 (3), 77-93.

Botswana Guardian. (2000). Employers are floundering the Employment for Non-Citizen Act, October 18, 9-10.

Botswana Telecommunications Corporation (2000). Localization Plan 2000 - 2004. Unpublished manuscript, Botswana Telecommunications Corporation, Gaborone.

Boutall, T. (1995). The good manager's guide. London: Management Charter Initiative.

Boyatzis, R.F. (1982). The competent manager: a model for effective performance. New York: Wiley.

Carretta, A. (1992). Career and succession planning. In Mitrani, A., Dalziel, M. \& Fitt, D. Competency based human resource management: Value driven strategies for recruitment, development and reward. London: Kagan Page.

Central Statistics Office. (2001). Republic of Botswana labour Statistics 1999. Gaborone: Printing and Publishing Services Department.

Cockerill, T., Hunt, J. \& Schroder, H. (2000). The high performance managerial competencies. Birmington: Brefi.

Chang, R.Y. (1996). Reinventing leadership for the 21st century. California: Irvine.

Cowan, L.G. (1990). Privatization in developing world. New York: Greenwood. 
Davis, L.D., Hellervik L.W. \& Sheard, J.L. (1989). Successful manager's handbook. Minneapolis: Personnel Decisions, Inc.

Davison, S.C. (1994). Creating a high performance international team. Journal of Management Development, 13 (2), 81-90.

Denge, R. (1991). Manpower development needs of the New South Africa, seen from the employees' point of view. Human Resources Development, 10, 2-4.

Digman, L.A. (1978). Management development: Needs and practices. Personnel Management, 21 (6) 45-56.

Dubois, D.D. (1993). Competency-based performance improvement: A strategy for organisational change. Washington DC: HRD.

Education Review Office (1995). Core competencies for school principals, 6, 1-19.

Galagan, P.A. (1990). Executive development in a changing world. Training and Development Journal, 6, 23-35.

Goffee, R. (1996). Managerial capability in the professional firm - assessing competencies in the city. The Journal Management Development, 15 (7), 4-15.

Hague, M.S. (1996). Public administration and policy in Botswana. International review of Administrative Sciences, 62, 315-329.

Hayes, J.L. (1983). CEOs in action. American Graduate School of International Management. Glendale: AZ.

Hite, L.M. \& McDonald, G. (1995). Gender issues in management development: implications and research agenda. Journal of Management Development, 14 (4), 5-15.

Hofmeyer, K.B. (1990). Management education for the nineties. South African Journal for Business Management, 21 (3), 102111.

Human, P. \& Human, L. (1989). Towards a better understanding of management development in South Africa. South African Journal for Business Management, 20 (1), 13-20.

Ishizaka, S. (1996). Management development in Toray - now and in the future. Journal of Management Development, 15 (8). England: MCB University.

Jackson, D. \& Humble, J. (1994). Middle managers: new purpose, new directions. The Journal of Management Development, 13 (3), 15-21.

Jacobs, R. (1989). Getting the measure of management competence. Personnel Management, 21 (6), 32-37.

Jorgensen,J.J., Hafsi, T. \& Kiggundu, M.N (1986). Towards a market imperfection: Theory of organisational structure in developing countries. Journal of Management Studies, 23 (4), 417-442.

Kakabadse, A., Ludlow, R. \& Vinnicombe, S. (1987). Working in organisations. Hamondsmith: Penguin.

Katz, R.L. (1974). Skills of an effective administrator. Harvard Business Review, 52, 90-102.

Khoza, R. (1994). The need for an Afrocentric management approach: A South African based management approach. In Christie, Lessem \& Mbiki, African Management: Philosophies, concepts and applications. Randburg: Knowledge Resources.

Khoza, R. (2002). Dancing to our own drum. Institute of People Management, 20 (5), 20-23.

Kouzes, J.M. \& Posner, B.Z. (1995). The leadership challenge: How to keep getting extraordinary things done in organisations ( $2^{\text {nd }}$ ed.). San Fransisco: Jossey - Bass.

Kumssa, A. (1996). Public administration in Botswana. International Review of Administrative Sciences, 62, 15-87.

Labbaf, H., Analoui, F. \& Cusworth, J.W. (1996). Senior managers' effectiveness: The case of the steel industry in Iran. Journal of Management Development, 15 (9), 47-63.

Larwood, L. \& Wood, M. (1995). Training women for management: changing priorities. Journal of Management Development, 14 (2), 54-64.

Leblanc, B. (1994). European competencies - Some guidelines for companies. Journal of Management Development, 13 (2), 7280.

Lewis, A.E. \& Fagenson, E.A. (1995). Strategies for developing women managers: how well do they fulfil their objectives? Journal of Management Development, 14 (2), 39-53.
Livingstone, J.S. (1977). Myth of the well-educated manager. Harvard Business Review, 13-18.

Mann, N. \& Staudenmier, J.M. (1991). Strategic shifts in executive development. Training and Development Journal, July, 37-40.

Margerison, C.J. (1984a). Where is management education going? - Some key operations. In Kakabadse, A. \& Mukin, S (Eds.), The future of Management Education. New York: Harper \& Row.

Margerison, C.J. (1984b). Chief executives' perception of managerial success factors. Journal of Management Development, 3 (4), 69-88.

Margerison, C.J. (1985). Achieving the capacity to manage. Journal of Management Development, 4 (3), 42-55.

Mbigi, L. (1994). The spirit of African management. In Christie, Lessem \& Mbigi. African Management: Philosophies, concepts and applications. Randburg: Knowledge Resources.

Mbokazi, S.Z. (1991). The Localization of the Kwa-Zulu Government Service. Unpublished doctoral thesis, University of South Africa, Durban.

McLagan, P. (1992). Management development and business ethics: A view from the U.K. Journal of Business Ethics, 11, 321-328.

McClelland, D. (1973). Assessing human motivation. New York: General Learning.

McDermott, I. (1995). Practical NLP for managers. Brookfield: Gower.

Meyer, T. (1996). Creating competitiveness through competencies: Currency for the $21^{\text {st }}$ century. Randburg: Knowledge Resources.

Miller, D.C. (1991). Handbook of research design and social measurement (5 $5^{\text {th }}$ ed.). London: Sage.

Mintzberg, H. (1980). The nature of managerial work. New York: Prentice-Hall.

Nel, C. (1994). Value-centred leadership: The journey of becoming a world-class organisation. In Christie, Lessem \& Mbiki. African Management: hilosophies, concepts and applications. Randburg: Knowledge Resources.

Peter, H.W. (1984). Developing managers for social change. Journal of Management Development, 3 (1), 16 - 27.

Profiles International, Inc. (2000). Checkpoint $360^{\circ}$ Leadership Development Program. California: Association of Test Publishers.

Reichel, A. (1996). Management development in Israel: current and future challenges. The Journal of Management Development, 15 (5), 22-36.

Rhinesmith, S.H. (1993). A manager's guide to globalization: Six keys to success in a changing world. Homewood: Irwin.

Rost, J.C. (1991). Leadership of the twenty-first century. New York: Praeger.

Saville \& Holdsworth Ltd. (1993). Inventory of Management Competencies. London: SHL.

Saville \& Holdsworth Ltd. (1994). Perspectives on Management Competencies. London: SHL.

Schein, E.H. (1987). Organisational behaviour at various systems levels. In Lorsch, J.W. Handbook of Organisational Behaviour. Englewood Cliffs: Prentice-Hall.

Schroder, H.M. (1989). Managerial competence - the key to excellence. Lowa: Kendall/Hunt.

Scott, B.P. (1996). Competency-based HRD. Princeton: Training House.

Sebetella, L.B. (2000). Advances towards quality and productivity practices in Botswana: A survey of leadership and human resources practices in the commercial parastatal sector. Unpublished master's thesis, University of Botswana, Gaborone.

Segal, B. (1991). Women in computing: elected papers, 1988-1990. London: Springer-Verlag.

Senge, P.M. (1993). Transforming the practice of management. Human Resource Development Quarterly, 4 (1), 5-32.

Simons, F. (2000). Impact of stress on women managers in South Africa. People Dynamics, 18 (8), 22-25. 
Stewart, A. (1987). Tomorrow's managers today: The identification and development of management potential. London: Institute of Personnel Management.

Tlou, T. \& Campbell, A. (1997). History of Botswana (2nd ed.). Gaborone: MacMillan.

Van der Merwe, L. (1994). A learning community with a common purpose. In Christie, Lessem \& Mbiki. African Management: Philosophies, concepts and applications. Randburg: Knowledge Resources.
Vincent, E. (1988). Developing managers for an international business. Journal of Management Development, 7 (6), 14-20.

Woodruffe, C. (1993). Assessment centres: Identifying and developing competence. London: Institute of Personnel Management.

Williamson, O.E. (1981). The modern corporation: Origins, evolution, attributes. Journal of Economic Literature, 19, 1537 1568 . 